\title{
Model of formation of the price of the state construction contract in the conditions of innovative development of economy
}

\author{
Tatiana Pinchuk $^{1, *}$, Irina Kazantseva $^{2}$, and Oleg Shlepnev ${ }^{1}$ \\ ${ }^{1}$ Irkutsk National Research Technological University, 664074, Lermontova str., 83, Irkutsk, Russia \\ ${ }^{2}$ Baikal State University, 664003, Lenin avenue, 11, Irkutsk, Russia
}

\begin{abstract}
Analysis and probation of the optimization model when determining the starting price of the construction contract in the current conditions of economic development. During the research, methods of economic theory, economic statistics and mathematical and statistical tools have been used. The methodical bases of the formation of the initial maximum contract price by dividing it into basic and manageable (controlled) components are considered. The division of the controlled factors into qualitative and quantitative indicators is proposed. The list of the basic expenses by division on the base and conditionally operated components at calculation of the starting price, which essentially differs from the technique of calculation of the estimated cost of the building order, is generated. A methodology for the formation of the contract price for the introduction of innovative investment and construction projects in the system of state procurement has been developed. Based on the research, it follows that, through the controlled factors, it is possible to influence the initial maximum contract price, in particular, by changing qualitative coefficients. As a part of the initial maximum contract price, there are basic and conditionally manageable components that change the contract price without adversely affecting other factors in the implementation of the state construction order. The integral qualitative indicator is a conditional coefficient, which depends on a certain set of qualitative components of the controlled factors, i.e. corresponds to the available set of significant indicators. It is enough to change the value of one of the qualitative indicators, and it will lead to a change in the initial maximum contract price through the integral indicator.
\end{abstract}

\section{Introduction}

Management of the investment cycle of construction requires the development of adequate measures to modern challenges of innovative forms and methods of the state regulation in the field of construction. The existing mechanism of placement and implementation of the state construction order allows us to conclude that the management system of the state

* Corresponding author: tanechka.pinchuk@list.ru 
procurement order is insufficient and requires further improvement based on the priorities of the innovation environment development and investment attractiveness of construction investment projects $[1,3]$. In particular, one of the main components for the placement of the state construction order is to determine the initial maximum contract price, which affects the conditions for the implementation of the state construction order $[2,4]$. The existing approach to the formation of the initial maximum price does not meet modern realities. The subject of the study is the mechanism of formation of the initial maximum contract price of innovative investment and construction projects within the framework of the state construction order [1, $3]$.

\section{Materials and methods}

From 01.01.2014, the Federal Law No. 44-FZ of 05.04.2013, which regulates relations for the implementation of purchases of goods, works and services to ensure state and municipal needs entered into force. This normative document replaced the Federal Law No. 94-FZ of 21.07.2005 "On the Placement of Orders for the Supply of Goods, the Performance of Work, and the Provision of Services for State and Municipal Needs." The law provides for significant changes in the rules for the implementation of public procurement, but with respect to the formation of the starting price of the state construction order, these changes are insignificant $[1,4]$. Based on that, it follows that for the effective innovative development of investment and construction sphere in the current situation, there is an urgent need to develop mechanisms to form the initial maximum contract price (the starting price), in order to implement innovative construction projects, improve the quality of construction and installation works, improve efficiency of investment and construction projects, and as a result, to improve infrastructure of the regions of the Russian Federation [5]. The new mechanism allows optimizing the price of the contract in the performance of the state construction order, increase the investment attractiveness of the projects in the field of construction and reconstruction, and improve the investment climate in the country as a whole and its regions [6]. As a result of the research, the methodology of forming the initial maximum contract price on the basis of the base and manageable components is proposed. At the core of the methodology, it was proposed to divide the factors in the composition of the manageable components: the cost of the land plot, the cost of connecting the facility to the engineering networks, the costs of social infrastructure, the costs of overcoming administrative barriers, the costs of ensuring the warranty period of operation of the facility, the life cycle costs of the facility (Figure 1) [1]. These factors have a direct impact on the formation of the initial maximum price of the contract. They are not taken into account separately by norms, but they have a huge influence on the final result of price formation (Table 1) [2]. 


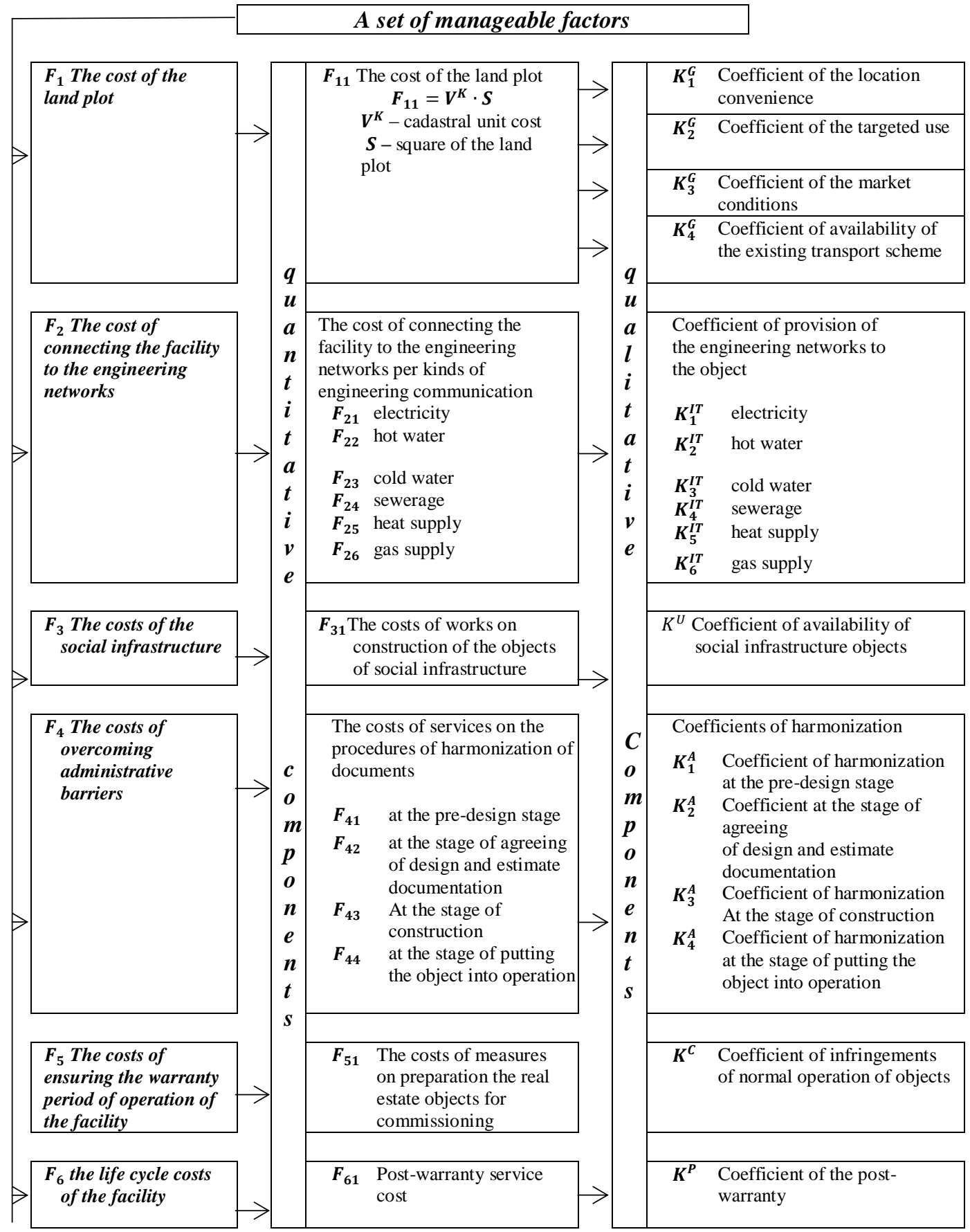

Fig. 1 Qualitative and quantitative indicators in the composition of conditionally controlled factors.

\section{Results}

Based on the base and manageable components, the optimization model for the formation of the initial maximum contract price (IMCP) in the current conditions of economic 
development is proposed (Figure 2) [1]. The starting or initial maximum price of the contract is formed based on the base and manageable components, determined by the formula (1).

$W$ - starting price of the contract (excluding VAT);

$$
\begin{gathered}
W=B+F \\
B=\sum_{k=1}^{10} B_{i}, \\
F=\sum_{j=1}^{6} F_{j},
\end{gathered}
$$

where $B$ is a part of the IMCP, calculated by the underlying factors, formula (2), $F$ is a part of the IMCP, calculated by the manageable factors, formula (3), $B_{i}$ are base factors, $F_{j}$ are manageable factors.

Calculation of the values of the base components in the starting value of the contract is carried out on the basis of the design and estimate method. Calculation of the values of the controlled (manageable) components (indicators) is based on the calculated parameters according to the formula (4)

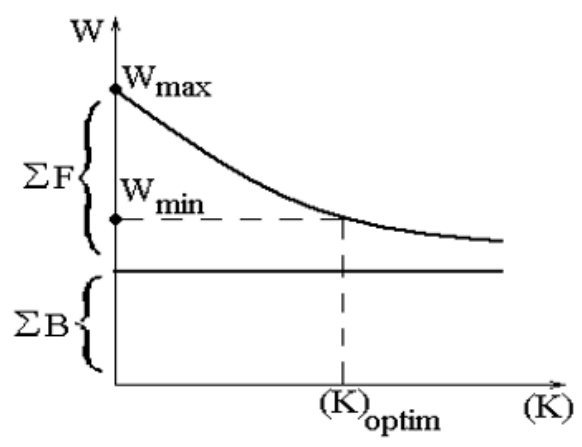

Fig. 2 Dependence of the initial maximum contract price from the integral qualitative indicator.

$$
F=F_{11}^{\boldsymbol{K}_{1}^{G} \cdot \boldsymbol{K}_{2}^{G} \cdot \boldsymbol{K}_{3}^{G} \cdot \boldsymbol{K}_{4}^{G}}+\sum_{i=1}^{6}\left(F_{2 i} \cdot K_{i}^{I T}\right)+F_{31} \cdot K^{U}+\sum_{i=1}^{4} \boldsymbol{F}_{\mathbf{4} i}^{\boldsymbol{K}_{i}^{S}}+\boldsymbol{F}_{\mathbf{5 1}}^{\boldsymbol{K}^{C}}+\boldsymbol{F}_{\mathbf{6 1}}^{\boldsymbol{K}^{\boldsymbol{P}}}
$$

Table 2. Qualitative indicators of the distribution of costs.

\begin{tabular}{|c|c|l|}
\hline № & Mark & \multicolumn{1}{c|}{ Name of qualitative components } \\
\hline 1 & $K_{1}^{G}$ & $\begin{array}{l}\text { coefficient of convenience of location, taking into account the remoteness of } \\
\text { the site from the central part of the city and the objects of social infrastructure }\end{array}$ \\
\hline 2 & $K_{2}^{G}$ & $\begin{array}{l}\text { coefficient of targeted use, taking into account the targeted use of the land } \\
\text { plot and the categories of residents and legal entities using this land plot }\end{array}$ \\
\hline 3 & $K_{3}^{G}$ & $\begin{array}{l}\text { coefficient of market conditions, taking into account the investment } \\
\text { attractiveness of the object }\end{array}$ \\
\hline 4 & $K_{4}^{G}$ & $\begin{array}{l}\text { coefficient of availability of the existing transport scheme, taking into } \\
\text { account the remoteness of the site from the main transport highways, the } \\
\text { need for works on the connection of the object to the existing transport } \\
\text { network }\end{array}$ \\
\hline 5 & $K_{i}^{T}$ & $\begin{array}{l}\text { coefficient of engineering communications on the object, taking into } \\
\text { account the costs of connecting the object to utility networks }\end{array}$ \\
\hline
\end{tabular}




\begin{tabular}{|c|c|l|}
\hline 6 & $K_{U}$ & $\begin{array}{l}\text { coefficient of availability of social infrastructure objects, taking into } \\
\text { account the remoteness of the site from social facilities }\end{array}$ \\
\hline 7 & $K_{i}^{A}$ & $\begin{array}{l}\text { coefficient of harmonization, taking into account various agreeing } \\
\text { procedures at different stages of design, construction and operation }\end{array}$ \\
\hline 8 & $K_{C}$ & $\begin{array}{l}\text { coefficient of violations of normal operation of facilities, taking into account } \\
\text { the operating conditions of the facility }\end{array}$ \\
\hline 9 & $K_{p}$ & $\begin{array}{l}\text { coefficient of post-guarantee maintenance, taking into account the } \\
\text { contractor's obligations in the process of operation }\end{array}$ \\
\hline
\end{tabular}

Quantitative indicators in the composition of the manageable components are set in the percentage terms from square meters and are focused on the statistical data. By the quantitative indicators, ranges are set, which are taken into account [7].

Weight coefficients of qualitative indicators are established based on expert estimates and empirical data [8].

The results obtained in the research have been tested at a social facility object in the Irkutsk region.

The calculation is based on the data from the Ministry of Regional Development of the Russian Federation, where the cost of 1 square. m., when calculating the initial maximum contract price, is taken equal to 33800 rubles $\left(V^{M}\right)$. The low-mobility component, calculated by base components, is equal to 93625.76 thousand rubles per the object as a whole on the basis of the design and estimate method of calculation. Dynamic component, calculated by controlled components (3) is equal to 8.62 thousand rubles / sq. m. Then the relative increase in the costs for the object due to the controlled components is $12.84 \%$ of $\mathrm{W}$ (1). This value will allow taking into account the costs of warranty and post-warranty maintenance of the facility, ensuring the life cycle of the property and other transaction costs $[1,15]$.

Based on the above, it follows that it is possible to influence the initial maximum price of the contract through the manageable factors (components) by changing the qualitative coefficients in particular [9].

The integral qualitative indicator is a conditional coefficient, which depends on a certain set of qualitative components of the controlled factors $[10,11,12,14,16]$. It is enough to change the value of one of the factors of qualitative indicators, and this will lead to a change in the initial maximum contract price through the integral indicator [13].

\section{Conclusion}

It has been revealed that the initial maximum price of the contract contains base and conditionally manageable (controlled) components that change the price of the contract without adversely affecting other factors in the implementation of the state construction order, in contrast to the existing system for determining the initial maximum contract price on the basis of the design and estimate method. A list of costs related to the base and manageable components of the estimated costs of the state construction order has been elaborated when the initial maximum contract price is formed, which is different from the existing costing system as a part of the contract price. A model for optimizing formation of the initial maximum contract price for the implementation of innovative investment and construction projects in the state construction order system has been developed [1].

\section{References}

1. T. O. Pinchuk, O. K. Shlepnev, N. O. Markova, Proceedings of High Schools. Investments. Building. Real Estate, 4, 131-138 (2017)

2. T. O. Pinchukк, Proceedings of the Irkutsk State Technical University, 10, 335-360 
(2013)

3. G. V. Khomkalov, Ye. A. Pankratyeva, Bulletin of the Irkutsk State Economic Academy, 17, 43-48 (1998)

4. T. G, Doroshenko, I. A. Sukhanova, Izvestiya of the Baikal State University, 26(4), 583-590 (2016).

5. I. F. Gareev, V. L. Rozhkov, A. G. Kotdusov, Russian Entrepreneurship, 16(19), 31493158 (2015)

6. V. V. Peshkov, P. I. Kasyanchik, Aconomic Annals XXI, 1(1-2), 50-53 (2014)

7. S. Frei, B. Tellenbach, B. Plattner. 0-Day Patch - exposing vendors (in)security performance, computer engineering and networks laboratory (TIK) (Swiss Federal Institute of Technology, Zurich, 2008)

8. NIST 800-30: risk management guide for information technology systems (Moscow, 2017)

9. Ernst \& Young, Outpacing change: Ernst \& Young's 12-th annual global information security survey (http://www.ey.com, 2009)

10. KPMG, E-crime survey 2009. Conducted by the 7th Annual e-Crime Congress in partnership with KPMG (http://www.symantec.com/connect/blogs, 2009)

11. World Economic Forum, Global competitiveness report 2008-2009 (Oxford University Press, New York, 2009)

12. G. Chen, Building construction: project management, construction administration, drawings, specs, detailing tips, schedules, checklists and secrets others don't tell you (ArchiteG, New York, 2010)

13. S. K. Sears, R. H. Clough, construction contracting: a practical guide to company management (Jhon Whiley \& Sons Inc., New York, 2015)

14. A. V. Bogoviz, Y. V. Ragulina, N. V. Sitorkina, Advances in Intelligent Systems and Computing, 622, 597-602 (2018)

15. R. L. Peurifoy, Construction planning, equipment \& management (McGraw Hill Education, 2014)

16. European Builders Confederation, Performance and Trends of the Construction Sector, 28, 11, (2017). 